\title{
En kvinne med kraftsvikt i armer og bein
}

\author{
En kvinne ble lagt inn på nevrologisk avdeling med tetraparese og mis- \\ tanke om hjerneslag. Det skulle vise seg at årsaken til symptomene var \\ en annen alvorlig lidelse med behov for rask behandling og omfattende \\ utredning.
}

Pasienten var en kvinne i slutten av 60-årene. Dagen før innleggelse hadde hun fått raskt innsettende kraftsvikt $i$ begge over- og underekstremiteter, og på innleggelsesdagen hadde hun ikke klart å komme seg opp av sengen. Hun ble innlagt på nevrologisk avdeling med spørsmål om hjerneslag. To år tidligere hadde hun hatt et høyresidig hjerneinfarkt, og hun hadde motoriske sekveler i form av lettgradig kraftnedsettelse $i$ venstre arm og bein. Hun sto på medikamentell sekundærprofylakse med acetylsalisylsyre, dipyridamol og atorvastatin. Hun hadde også osteoporose, behandlet med kalsium- og Dvitamintilskudd og alendronat, og kronisk obstruktiv lungesykdom med inhalasjonsbehandling i form av indakaterol, budesonid og formoterol. Pasienten hadde vært plaget med løs avføring i flere måneder. Dette var forsøkt behandlet med probiotikakapsler uten særlig effekt. Appetitten var blitt dårligere, og hun anslo et vekttap på $10 \mathrm{~kg}$ de siste tre månedene, svarende til $12 \%$ av kroppsvekten. Hun hadde ikke hatt oppkast. Pasienten fortalte om et økt alkoholforbruk i samme periode, med et gjennomsnittlig dagsinntak på 1-2 alkoholenheter i form av brennevin. Ved den aktuelle kliniske undersøkelsen ble det funnet symmetrisk kraftsvikt grad $4 i$ overekstremitetene og grad $3 i$ underekstremitetene. Finmotorikken $i$ hendene var også svekket, venstre side noe mer enn høyre. Av øvrige kliniske funn hadde hun svake, symmetriske senereflekser, utslukkede akillesreflekser og lett oppadvendte plantarreflekser. Hun hadde ingen smerter, og sensibiliteten var normal og sidelik i overog underekstremitetene. EKG viste atrieflimmer, og perifer puls var uregelmessig med frekvens på 80-90 per minutt.

Anamnese og kliniske funn ga mistanke om et nytt hjerneslag. Pasientens motoriske utfall var symmetriske og affiserte både over- og underekstremiteter. Man kunne dermed tenke seg at det var snakk om en spinal lesjon i cervikalnivå, eventuelt en lesjon i venstre hemisfære som sammen med sekveler fra det tidligere hjerneinfarktet ga et symmetrisk symptombilde. Differensialdiagnostisk kunne gastrointestinale symptomer i forkant av symmetrisk kraftsvikt gi mistanke om Guillain-Barrés syndrom. Det kunne også tenkes at symptomene skyldtes myelopati av ikke-vaskulær årsak, for eksempel demyeliniserende sykdom eller en spinal abscess. Det var ikke opplysninger om traume i sykehistorien.

CT caput viste normale funn, og MR viste ikke tegn til ferske infarkter, verken i hjernen eller i ryggmargen. Et nytt slag var derfor lite sannsynlig, og årsaken til symptomene var uklar. Etter at pasienten kom til sengepost, ble vakthavende lege varslet om at laboratoriet hadde målt en kaliumverdi på 1,4 mmol/l (3,5-5,0 mmol/l). Laboratoriet var overbevist om at det svært lave prøvesvaret måtte skyldes feil i prøvebehandlingen, og det ble straks tatt nye blodprøver. De nye prøvene bekreftet imidlertid at pasienten hadde alvorlig hypokalemi, da serumkalium nå ble målt til 1,5 mmol/l. Blodprøvene viste også alvorlig hypomagnesemi, og det ble målt lave verdier av natrium og kalsium (tab 1) (1). Pasienten ble lagt pà telemetri og raskt overflyttet til medisinsk intensiv- og overvåkingsavdeling for korrigering av elektrolyttforstyrrelsene.

Blodprøvene viste at pasienten hadde alvorlig hypokalemi og alvorlig hypomagnesemi. Sykehistorien ga opplysninger om redusert matinntak, høyt alkoholforbruk og langvarig diaré, forhold som alle kan føre til lave verdier av kalium og magnesium (2-4). Pasienten hadde ikke brukt diuretika, som er blant de vanligste årsakene til hypokalemi, og hun hadde heller ikke hatt oppkast. Alvorlig hypokalemi kan gi både pareser og hjertearytmier, som hos vår pasient. Andre potensielle organmanifestasjoner er rabdomyolyse, kramper og respirasjonsstans. Pasienter med moderat til alvorlig hypokalemi (serumverdi under $3,0 \mathrm{mmol} / \mathrm{l}$ ) eller symptomgivende hypokalemi trenger rask behandling med intravenøs kaliumtilførsel, og ved alvorlig hypokalemi med arytmier er monitorering på overvåkingsenhet nødvendig (5).

På medisinsk intensiv- og overvåkingsavdeling ble det tatt blodgass som viste metabolsk alkalose med lett forhøyet laktat. Det ble gitt intravenøs $\mathrm{NaCl}$ tilsatt kalium og

\author{
Sander Johan Aarli \\ sander.aarli@student.uib.no \\ Nevrologisk avdeling
}

Tarek Ramzi Elia Mazzawi

Gastroenterologisk seksjon Medisinsk avdeling

Geir Olve Skeie

Nevrologisk avdeling

Haukeland universitetssykehus 
Tabell 1 Laboratorieverdier ved innkomst

\begin{tabular}{|c|c|}
\hline Laboratorieprøver (enhet) & Pasientens verdi (referanseverdi ${ }^{1}$ ) \\
\hline S-kalium (mmol/l) & $1,5(3,5-5,0)$ \\
\hline S-magnesium (mmol/) & $0,38(0,71-0,94)$ \\
\hline S-natrium (mmol/l) & $131(137-145)$ \\
\hline S-kalsium (mmol/l) & $1,59(2,20-2,55)$ \\
\hline S-fritt kalsium (mmol/l) & $0,92(1,13-1,28)$ \\
\hline B-hemoglobin (g/dl) & $12,4(11,7-15,3)$ \\
\hline MCV (fl) & $97(82-98)$ \\
\hline B-leukocytter $\left(\cdot 10^{9} / \mathrm{l}\right)$ & $14,6(3,5-11,0)$ \\
\hline B-trombocytter $\left(\cdot 10^{9} / l\right)$ & $392(165-387)$ \\
\hline S-CRP (mg/l) & $40(<5)$ \\
\hline S-kreatinin $(\mu \mathrm{mol} / \mathrm{l})$ & $86(45-90)$ \\
\hline S-eGFR (ml/min/1,73m²) & $57(>54)^{2}$ \\
\hline S-ALAT (U/L) & $44(10-45)$ \\
\hline S-gamma GT (U/l) & $36(10-75)$ \\
\hline S-albumin (g/L) & $18(39-48)$ \\
\hline INR & $1,5(<1,1)$ \\
\hline S-CK (U/L) & $992(35-210)$ \\
\hline S-ferritin $(\mu \mathrm{g} / \mathrm{l})$ & $1840(18-240)$ \\
\hline S-jernbindingskapasitet $(\mu \mathrm{mol} / \mathrm{l})^{3}$ & $22(49-83)$ \\
\hline S-transferrinmetning $(\%)^{3}$ & $30(20-35)$ \\
\hline S-TSH (mU/l) & $2,06(0,40-4,5)$ \\
\hline
\end{tabular}

1 Referanseverdier for kvinner > 60 år i henhold til analyseoversikten, Helse Bergen (1)

2 Referanseverdi for kvinner 60-69 år i henhold til Fürst Medisinsk Laboratorium

3 Prøve tatt senere i utredningsforløpet

magnesium, og etter 12 timer hadde serumkalium steget til 2,5 mmol/l. Blodgassverdiene var nå begynt å normalisere seg, med pH 7,44 (7,36-7,44), pCO 4,6 (4,5-6,1) og $\mathrm{HCO}_{3}-24$ (22-26) (5). Etter 16 timer viste EKG omslag til sinusrytme med forlenget $P Q$-tid og T-bølgeforandringer (fig 1). Etter ytterligere åtte timer var serum-kalium kommet opp til 3,7 mmol/l, og verdien ble videre stabilisert mellom 3,7 mmol/l og 4,2 $\mathrm{mmol} / \mathrm{l}$ (tab 2). Pasienten fikk gradvis bedre kraft i over- og underekstremitetene. Øvrige blodprøver (tab 1) viste normal kreatinin, MCV, ALAT og gamma-GT. Albumin var svært lav, mens INR var forhøyet. Det ble også målt elektrolytter i spoturin, som viste høy urin-kalium og kalium/kreatinin-ratio og økt fraksjonell ekskresjon av magnesium (FEMg) (tab 2).

Da elektrolyttforstyrrelsen var korrigert, ble pasienten overført til gastroenterologisk seksjon. Det ble utført screening for ernæ- ringsmessig risiko (NRS 2002), der pasienten skåret 4 lskår $\geq 3$ indikerer ernæringsmessig risiko og behov for målrettet behandling), og det ble startet forsiktig reernæring. Elektrolyttstatus ble målt flere ganger $i$ døgnet de første to dagene og deretter én gang daglig. Etter at reernæring var startet opp, falt serum-fosfat til 0,48 mmol/l, og kalium- og magnesiumverdiene var igjen synkende. Dette ble tolket som begynnende reernæringssyndrom, og pasienten fikk monokaliumfosfat intravenøst med påfølgende normalisering av elektrolytter. Intravenøs kalium- og magnesiumbehandling ble vedlikeholdt, og det ble også gitt kalium og magnesium peroralt. I tillegg fikk pasienten vitamin $B$ - og C-injeksjon på grunn av underernæring og metningsdose konakion grunnet INR på 2,0 uten marevaninntak. Etter en uke ble det målt normal INR-verdi. Det ble også tatt avføringsprøver som var negative for tarmpatogener og Clostridium.
Forhøyet urin-kalium og kalium-kreatininratio tydet på renalt kaliumtap, og økt FEMg antydet samtidig renalt magnesiumtap. Langvarig alkoholoverforbruk kan føre til tubulær dysfunksjon med økt renalt tap av magnesium og kalium, og dette var en mulig forklaring hos vår pasient $(3,6)$. Til tross for økt alkoholforbruk var ikke MCV eller gammaGT forhøyet. Lav albumin og forhøyet INR tydet på svikt i leverens syntesefunksjon, og den svært lave albuminverdien var trolig også et uttrykk for alvorlig underernæring. I tillegg til de renale årsakene til elektrolyttforstyrrelsene tyder sykehistorien og funnene på samtidige ekstrarenale årsaker i form av kronisk underernæring og tap av elektrolytter gjennom gastrointestinalkanalen. INR-verdien ble normalisert etter behandling med konakion, mens albuminverdien steg i takt med at pasienten ble reernært.

For å avdekke eventuell leverpatologible det gjort ultralyd abdomen, som viste leversteatose og ascites, og det ble gjort CT abdomen med spørsmål om malignitet. CT viste ingen fokal leverpatologi, men det ble funnet veggfortykkelse og kontrastoppladning $i$ coecum, colon ascendens og colon descendens. Dette ga mistanke om kolitt som årsak til pasientens langvarige diaré. Koloskopi viste ødematøse slimhinner med tydelige kartegninger og redusert haustrering, forenelig med ulcerøs kolitt.

Ulcerøs kolitt blir sjelden påvist i pasientens aldersgruppe, men røntgenologiske og endoskopiske funn pekte i retning av denne diagnosen. Med tanke på alder kunne man ikke utelukke en bakenforliggende infeksiøs årsak.

Grunnet mistanke om ulcerøs kolitt fikk pasienten behandling med mesalazin i tillegg til prednisolon i gradvis nedtrappende doser. Flagyl ble lagt til med tanke på mulig infeksiøs årsak. Etter behandlingsstart ble pasientens avføring fastere. En ny ultralydundersøkelse av leveren viste ingen ascites eller tegn til steatose. Biopsier fra colon viste ikke sikre tegn til ulcerøs kolitt, men det ble beskrevet lette inflammatoriske forandringer i tarmveggen.

Pasienten fikk gradvis krefter igjen etter at elektrolyttforstyrrelsene var korrigert og reernæring igangsatt, men hun hadde fortsatt behov for hjelp til stell og var avhengig av rullator for å gå. Hun ble mobilisert og trente med fysioterapeut på sengeposten. Nevrologisk undersøkelse ti dager etter innleggelse viste merkbart bedre kraftprestasjoner i overekstremitetene (grad 5), men fortsatt svekket kraft i underekstremitetene (grad 3-4). Finmotorikken var også tydelig bedret, og pasienten følte seg bedre selv om hun fortsatt var plaget med slapphet og løs 


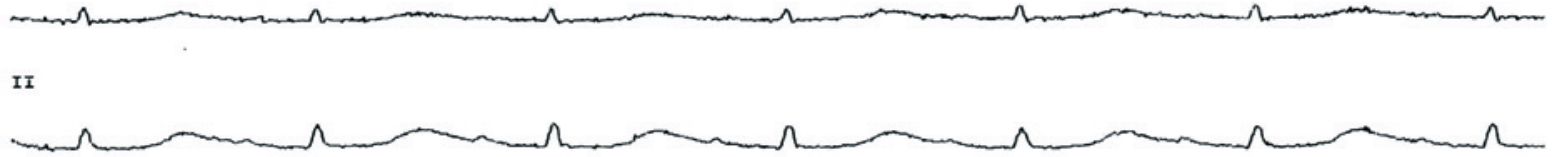

III

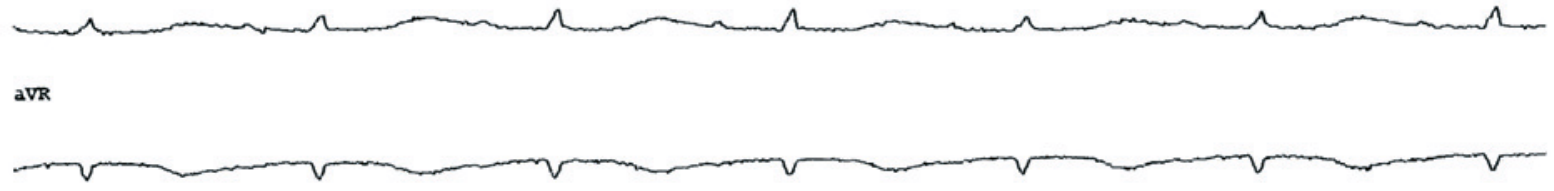

avs

avp

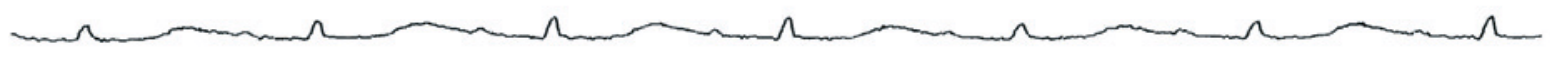

Speed: $50 \mathrm{~mm} / \mathrm{sec}$

Figur 1 EKG viser sinusrytme med frekvens 79 per minutt, forlenget PQ-tid (0,23 s, referanse 0,12-0,20) og uspesifikke T-bølgeforandringer

avføring. Refleksene var fremdeles symmetrisk svake. Ved utreise, tre uker etter innleggelsen, hadde hun normale elektrolyttverdier (tab 2). Hun ble skrevet ut til et korttidsopphold på sykehjem frem til hun hadde krefter nok til å klare seg selv hjemme.

Seks måneder etter innleggelsen var pasienten til poliklinisk kontroll på medisinsk avdeling. Hun følte seg i bra form og var tilbake på samme funksjonsnivå som før sykdomsepisoden. Avføringen var normalisert, og hun hadde stabil vekt. Hun brukte fremdeles mesalazin. Det ble målt moderat forhøyet kalprotektin i avføringen $1294 \mathrm{mg} / \mathrm{kg}$, ref. 0-50, kalprotektin ble ikke målt i forbin- delse med innleggelsen). Dette støttet opp under diagnosen ulcerøs kolitt, selv om biopsiene tatt ved diagnosetidspunktet ikke var helt konklusive.

\section{Diskusjon}

Hypokalemi med paralyse er et multifaktorielt symptombilde med global kraftsvekkelse og lav serum-kalium som fellesnevnere. Kraftsvekkelsen skyldes redusert ekstracellulær kaliumkonsentrasjon som fører til lavere hvilemembranpotensial i muskelceller og gjør cellene ikke-eksitable (2).

Stedwell og medarbeidere presenterer en omfattende oversikt over årsaker til hypo- kalemi med paralyse (ramme 1) (2). Hovedskillet går mellom tilstander med transcellulært kaliumskifte, der kalium transporteres fra blodbanen og inn i cellene, og tilstander med et reelt kaliumunderskudd, enten på grunn av manglende inntak eller på grunn av økt tap gjennom urinveier eller gastrointestinalkanalen. Tilstander forbundet med transcellulært kaliumskifte er familiær periodisk paralyse og hypertyreose som kan gi anfall med global kraftsvekkelse fra 3-4 timer til over et døgn. Overdosering av insulin og metabolsk eller respiratorisk alkalose kan også føre til transcellulært kaliumskifte.

Tilstander med reelt kaliumunderskudd

Tabell 2 Laboratorieverdier - forløp

\begin{tabular}{|c|c|c|c|c|c|c|c|c|c|c|}
\hline Laboratorieprøver (enhet) & $\begin{array}{l}\text { Referanse- } \\
\text { område }^{1}\end{array}$ & $0 \mathrm{t}$ & $5 t$ & $12 \mathrm{t}$ & $20 \mathrm{t}$ & $2 \mathrm{dg}$ & $4 d g$ & $7 \mathrm{dg}$ & $14 \mathrm{dg}$ & $21 \mathrm{dg}^{2}$ \\
\hline S-kalium (mmol/l) & $3,5-5,0$ & 1,5 & 2,8 & 2,5 & 3,7 & 4,1 & 3,2 & 3,1 & 3,9 & 3,7 \\
\hline S-magnesium (mmol/l) & $0,71-0,94$ & 0,38 & 0,78 & 1,44 & 1,24 & 0,93 & 0,59 & 0,57 & 0,69 & 0,71 \\
\hline S-fosfat (mmol/l) & $0,85-1,50$ & --- & 0,88 & 0,76 & 0,81 & 0,48 & 1,33 & 1,26 & --- & 1,05 \\
\hline INR & $<1,1$ & 1,5 & --- & 1,7 & --- & 2,0 & --- & 1,0 & --- & --- \\
\hline U-kalium (mmol/l) & 3 & --- & --- & --- & 27 & --- & --- & --- & --- & --- \\
\hline U-kreatinin (mmol/l) & $2,2-35,4$ & --- & --- & --- & 6,4 & --- & --- & --- & --- & --- \\
\hline U-kalium/ U-kreatinin-ratio & 3 & --- & --- & --- & 4,22 & --- & --- & --- & --- & --- \\
\hline U-magnesium/ U-kreatinin-ratio & 3 & --- & --- & --- & 2,45 & --- & --- & --- & --- & --- \\
\hline $\begin{array}{l}\text { Fraksjonell ekskresjon } \\
\text { av magnesium (FEMg) (\%) }\end{array}$ & 3 & --- & --- & --- & 18,6 & --- & --- & --- & --- & --- \\
\hline
\end{tabular}

${ }^{1}$ Analyseoversikten, Helse Bergen (1)

2 Utreisetidspunkt

${ }^{3}$ Standardisert referanseområde i spoturin foreligger ikke 
RAMME 1

Årsaker til hypokalemisk paralyse (2)

Transcellulært kaliumskifte

- Familiær periodisk paralyse

- Tyreotoksisk periodisk paralyse

- Andre: Insulinoverdosering, respiratorisk/ metabolsk alkalose, bariumforgiftning

\section{Kaliumunderskudd}

- Renalt tap:

- Renal tubulær acidose (distal eller proksimal)

- Hyperaldosteronisme (Conns syndrom)

- Andre: Nefrotisk syndrom, tiazidbruk, diabetisk ketoacidose, akutt tubulær nekrose

- Ekstrarenalt tap:

- Cøliaki

- Bakterielle, inflammatoriske enteritter (Salmonella, Yersinia) og parasittinfeksjoner (Strongyloides)

- Kort tarm-syndrom

- Ulcerøs kolitt og andre tilstander med diaré eller malabsorpsjon

kalles også hypokalemiske ikke-periodiske paralyser. Man skiller mellom renale og ekstrarenale årsaker til hypokalemi med paralyse. Den hyppigste renale årsaken er renal tubulær acidose (7), men andre årsaker, som nefrotisk syndrom, diabetisk ketoacidose og bruk av diuretika (spesielt tiazider), er også beskrevet. Hypokalemi med paralyse grunnet ekstrarenalt tap kan i teorien være forårsaket av alle tilstander som gir diaré eller malabsorpsjon, og tilfeller forårsaket av cøliaki, gastroenteritt og kort tarm-syndrom er omtalt (2). Hypokalemi og samtidig hypomagnesemi kan skyldes ekstrarenalt elektrolyttap gjennom gastrointestinalkanalen, for eksempel grunnet diaré eller malabsorpsjon. Det kan også komme av renalt tap ved alkoholisk skade av nyretubuli.

Et sentralt aspekt ved behandling av hypokalemi med paralyse er å identifisere den underliggende årsaken til tilstanden. Sykehistorien er av betydning for å skille periodisk og ikke-periodisk parese samt for å avdekke andre forhold som kan forklare symptomene, som diaré eller bruk av tiazider. Lin og medarbeidere har vist at analyse av spoturin og arteriell blodgass har stor diagnostisk verdi; lav kalium-kreatinin-ratio i spoturin (U-kalium/U-kreatinin) og fravær av metabolske syre-base-forstyrrelser taler for periodisk parese, mens høy kalium-kreatinin-ratio ledsaget av metabolsk alkalose eller acidose tyder på ikke-periodisk parese $(8,9)$. I en prospektiv studie utført av Sung og medarbeidere er det i tillegg vist at kaliumekskresjon gjennom urinveiene kan brukes til å skille renale og ikke-renale årsaker til ikke-periodisk hypokalemi med paralyse (10).

Vår pasient hadde et reelt kaliumunderskudd med ikke-periodiske pareser. På innleggelsesdagen hadde hun metabolsk alkalose, og det ble målt høy kalium-kreatinin-ratio i spoturin, godt forenelig med konklusjonene til Lin et al. I utredningen fremkom både renale og ekstrarenale forklaringer på elektrolyttforstyrrelsene. Urin-kalium over $15-20 \mathrm{mmol} / \mathrm{l}$ i spoturin tyder på kaliurese hos en hypokalemisk pasient $(8,11)$, og dette støttes av kaliumkreatinin-ratio over 2 (8). Pasienten hadde i tillegg FEMg over $4 \%$ som taler for renalt magnesiumtap (4). Høyt alkoholinntak over tid kan føre til tubulær dysfunksjon som gir økt renalt magnesiumtap og påfølgede økt kaliurese og hypokalemi $(3,6)$. Dette var en sannsynlig forklaring hos vår pasient. De ekstrarenale årsakene til pasientens elektrolyttforstyrrelser var kronisk underernæring og økt elektrolyttap gjennom gastrointestinalkanalen.

Pasienten i vår kasuistikk hadde ekstremt lav serum-kalium, svarende til de aller laveste verdiene $\mathrm{i}$ Lin og medarbeideres studie av 43 pasienter med alvorlig hypokalemi (verdier fra 1,5-2,6 mmol/l) (9). Også sammenliknet med Sung og medarbeideres studie av 58 pasienter med ikke-periodisk hypokalemi med paralyse og gjennomsnittlig serum-kalium på $1,8 \pm 0,2 \mathrm{mmol} / 1$ fremstår verdien til vår pasient som særskilt lav (10).

Ved hypokalemi med paralyse er behandlingen intravenøs kaliumtilførsel, og pasienten vår fikk dette med god effekt både på elektrolyttforstyrrelsen, hjertearytmien og paresene. Etter omslag til sinusrytme viste EKG økt PQ-tid og T-bølgeforandringer, som er typiske funn ved hypokalemi $(1,4)$. Karakteristiske U-bølger ble ikke observert. Pasienten ble videre utredet på gastroenterologisk seksjon, og det ble påvist alvorlig underernæring og mistanke om svikt i leversyntesefunksjon. INR-verdien ble normalisert etter tilførsel av konakion. Gamma-GT og MCV var ikke forhøyet til tross for alkoholoverforbruk. I studien til Hock og medarbeidere fremkommer det imidlertid at sensitiviteten til disse biomarkørene ikke er veldig høy (12). Forklaringen på pasientens kroniske diaré var trolig ulcerøs kolitt, selv om biopsisvarene ikke var helt konklusive. Ved poliklinisk kontroll ble det målt moderat forhøyet kalprotektin, og pasienten var symptomfri og hadde normal avføring etter seks måneder med medikamentell behandling, noe som støttet opp om denne hypotesen.

Vi mener denne sykehistorien er lærerik, da den presenterer et sjeldent alvorlig tilfelle av en forholdsvis vanlig elektrolyttforstyrrelse. Den diagnostiske utredningen og de sammensatte årsakene som ble avdekket kan også være av interesse.
Pasienten har gitt samtykke til at artikkelen blir publisert.

\section{Sander Johan Aarli (f. 1990)}

er medisinstudent med lisens ved Universitetet i Bergen.

Forfatter har fylt ut ICMJE-skjemaet og oppgir ingen interessekonflikter.

\section{Tarek Ramzi Elia Mazzawi (f. 1982)}

er lege i spesialisering i gastroenterologi og ph.d.-kandidat ved Universitetet i Bergen.

Forfatter har fylt ut ICMJE-skjemaet og oppgir

ingen interessekonflikter.

\section{Geir Olve Skeie (f. 1964)}

er spesialist i nevrologi og overlege. Forfatter har fylt ut ICMJE-skjemaet og oppgir ingen interessekonflikter.

\section{Litteratur}

1. Helse Bergen. Analyseoversikten. http://analyseoversikten.no (19.8.2015)

2. Stedwell RE, Allen KM, Binder LS. Hypokalemic paralyses: a review of the etiologies, pathophysiology, presentation, and therapy. Am J Emerg Med 1992; 10: 143-8.

3. Elisaf M, Liberopoulos E, Bairaktari E et al. Hypokalaemia in alcoholic patients. Drug Alcohol Rev 2002; 21: 73-6.

4. Pham PC, Pham PA, Pham SV et al. Hypomagnesemia: a clinical perspective. Int J Nephrol Renovasc Dis 2014; 7: 219-30.

5. Schaefer TJ, Wolford RW Disorders of potassium. Emerg Med Clin North Am 2005; 23: 723-47, viii-ix.

6. Elisaf M, Merkouropoulos M, Tsianos EV et al. Pathogenetic mechanisms of hypomagnesemia in alcoholic patients. J Trace Elem Med Biol 1995 9: $210-4$

7. Ahlawat SK, Sachdev A. Hypokalaemic paralysis. Postgrad Med J 1999; 75: 193-7.

8. Lin SH, Chiu JS, Hsu CW et al. A simple and rapid approach to hypokalemic paralysis. Am J Emerg Med 2003; 21: 487-91.

9. Lin SH, Lin YF, Chen DT et al. Laboratory tests to determine the cause of hypokalemia and paralysis. Arch Intern Med 2004: 164: 1561-6.

10. Sung CC, Cheng CJ, Chiang WF et al. Etiologic and therapeutic analysis in patients with hypokalemic nonperiodic paralysis. Am J Med 2015; 128: 289-96.e1

11. Halperin ML, Kamel KS. Potassium. Lancet 1998 352: $135-40$.

12. Hock B, Schwarz M, Domke I et al. Validity of carbohydrate-deficient transferrin (\%CDT), gammaglutamyltransferase (gamma-GT) and mean corpuscular erythrocyte volume (MCV) as biomarkers for chronic alcohol abuse: a study in patients with alcohol dependence and liver disorders of nonalcoholic and alcoholic origin. Addiction 2005; 100 $1477-86$

Mottatt 4.11. 2014, første revisjon innsendt 18.4 2015, godkjent 19.8. 2015. Redaktør: Lise Mørkved Helsingen. 